\title{
The Qa Vaccine For Resilience In The New Normal: Sel Teaching Practices + E-Services
}

\author{
Shielilo R. Amihan \\ University of Perpetual Help System-DALTA (UPHSD), Calamba City, Philippines
}

\{shielilo.amihan@perpetualdalta.edu.ph\}

\begin{abstract}
This quantitative study of 327 online learners determined the interplay of the educational services and the integration of SEL practices into instruction as a vaccine towards developing resilience during the new normal. Correlation and comparative analyses of the data from an e-survey, with statistical powers of .999 and .986 respectively, found out that during the new normal: 1. the UPHSD have adapted well in the delivery of educational services, most notably through its online instruction, virtual administrators and Philosophy, and Objectives; 2. the teachers have implemented well the SEL teaching practices through social and instructional interaction; 3 . there is still room for improvement in the delivery of educational services of UPHSD, and implementation of SEL teaching practices focused on old students, and 4. resilient learners may be developed through continuous improvement on the delivery of appropriate educational services of UPSHD towards excellence. The study recommends the infusion of concrete SEL programs in all the educational services as part of QA strategies.
\end{abstract}

Keywords: SEL Teaching Practices, New Normal, e-Services, Quality Assurance, UPHSD

\section{Introduction}

The pandemic has disrupted learning on a global scale. The positive gains attained in meeting the global targets set in the Sustainable Development Goals (SDG) related to quality education have been massively downturned. The situation warrants close attention, considering that there seems to be no definite end to the crisis while its impact worsens. The negative effects on educational institutions could not be more overstated. Amid these disruptions, though, institutions continue to survive and even thrive.

The relevance of education may mean how responsive schools are at adapting to the needs and demands of the current times and the impending future. It is perhaps the main criterion in defining quality education during the new normal. The pandemic is the context in which education operates at present and in the foreseeable future. Education at present is highly dependent on technology. While it is seen as a tool to address the education divide brought by restrictions to physical classes, it has also become a serious stressor for the main stakeholders - the learners. Failure to mitigate this divide coupled with the psychological stress may lead to more serious consequences-- a crisis in education. 
It is incumbent for QA efforts of institutions to ensure relevant quality education, as evidenced by the new normal-customized quality of services and outcomes. These are the main parameters in determining quality in the academe, which remain constant even with the drastic changes in the educational landscape. The delivery of services has migrated to online platforms and provisions of e-services, with the welfare of learners in mind. During this crisis, the learners are psychologically vulnerable. There is a need to address this for better learning outcomes to occur. The pandemic is here to stay. The practical action for schools is to find a vaccine to prevent its adverse effects. Hence, conscious efforts should be made to incorporate socio-emotional learning (SEL) into the curriculum and instruction. Quality assurance, therefore, may be redefined as pandemic-proofing of learning through assuring the delivery of SEL-integrated instruction and e-services. It is in this context that the researcher conducts this study. The main objective of the study is to determine the interplay of the quality of educational services and the integration of SEL practices into instruction in the new normal. Specifically, it aims to determine the following:

a. The profile of the online student-respondents;

b. The level of quality of education through the e-delivery of the educational services during the new normal;

c. The extent of implementation of SEL practices in the new normal of instruction in terms of Social Interaction and Instructional Interaction;

d. The significant difference in the assessments on the level of quality of education of the respondents when grouped to profile;

e. The significant difference in the assessments on the implementation of SEL practices of the respondents when grouped to profile;

f. The significant relationship of the implementation of SEL practices and the quality of education, through the delivery of the following services, during the new normal.

\subsection{Review of Related Literature}

SEL programs are not one-size-fits-all. Schools need to design and implement SEL programs, considering the diversity in schools. Hence, it may be logical for educational leaders to gain feedback from students and teachers with varying circumstances. The analysis and interpretation of the effectiveness of SEL program implementation may, therefore, be context-specific. This assessment would yield concrete and actionable recommendations for program improvement or enhancement (Barnes \& McCallops, 2019; Long \& National Association of State Boards of Education, 2019).

Studies highlighted the timely need to incorporate SEL into teaching to prepare students for a learning mode in a distance learning set-up that is potentially traumatic (A Critical Time for Well-Being, 2020; Lorenzo, Eichert \& Elias, 2019). There have been mounting calls for developing social and emotional knowledge, attitudes, and skills as among the crucial competency outcomes needed for the $21^{\text {st }}$ century, highlighting its effect on future success. This entails integrating SEL into instruction, including assessment (American Institutes for Research, 2015; Duncan, Washburn, Lewis, Bavarian, DuBois, Acock, Vuchinich \& Flay, 2020). However, its implementation should transcend to the macro-level educational services provides. This commits to an evidenced-based approach of SEL, delivering skills-based outcomes (Porche, Grossman, Biro, MacKay \& Rivers, 2014; Schwartz \& Dusenbury, 2018; Goh \& Connolly, 2020).

QA translates to quality services and outcomes of an institution (Lundberg \& Schreiner, 2004). However, quality in education should be engrained in the learning content and 
pedagogy (Puzziferro \& Shelton, 2008). Commitment to quality in education requires continuous improvement through self-realization. Struggles and success stories are part of the journey to quality. The QA processes should always incorporate feedback mechanisms to comply with certain declared standards, hence determining the quality and effectiveness of educational services (Eaton, 2011; Ryan, 2015).

Various frameworks have already been forwarded, which include student success as an indicator of school quality. Many studies have also stressed the inclusion of school climate and SEL as part of accountability and continuous improvement systems. The informed decisions for quality in education must consider the SEL measures (Melnick, Cook-Harvey \& Darling-Hammond, 2017). Quality program blueprints must include SEL as among its core considerations, especially during these times. There has been a steady shift towards focusing on the whole child by integrating SEL rather than focusing on cognitive score metrics (Oberle, Meyers, \& Weissberg, 2016; Mehta, 2020).

\subsection{Conceptual Framework}

The study is guided by the long-term global goals for education as spelled-out in the SDG of 2030 goal no. 4, on Quality Education. Specifically, it relied heavily on the framework developed by Yoder (2014) in the SEL Teaching Practices of the Center on Great Teachers and Leaders, as reflected in Figure 1.

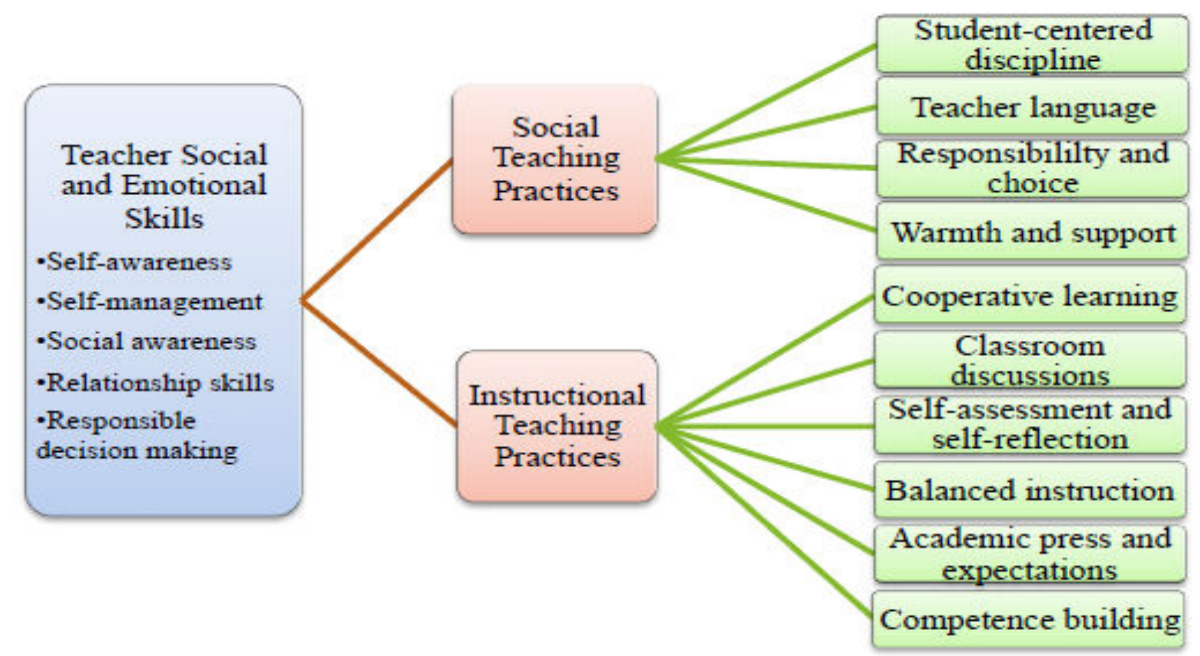

Fig 1. Relationship between Teacher SEL Skills and the SEL Teaching Practices

The framework highlighted the transfer of SEL skills from the teachers to the learners through social and instructional teaching practices. The SEL social teaching practices involve the student-centered discipline, teacher language, responsibility and choice, and warmth and support components. The SEL instructional teaching practices include cooperative learning, classroom discussions, self-assessment and self-reflection, balance instruction, academic press and expectations, and competence building. In this study, the researcher excluded academic press and expectations and competence-building due to difficulty in the light of the new normal of education. 


\section{Methodology}

\subsection{Design}

The quantitative study utilized both correlational and comparative designs. This methodology determines the relationship between variables and the variances that exist between and among groups of respondents. The study attempted to establish the association between the quality of education of an institution through the delivery of the e-services and the extent to which the SEL practices are implemented by the faculty during the new normal. In both these variables, the responses are compared based on their cluster affiliation and yearlevel.

\subsection{Respondents of the Study}

To provide the context, tables A and B display the distribution based on the availability of resources and internet connectivity. The secondary data presented are results of a survey of the institution through the Research and Development Center (RDC) conducted during the first week of the current semester.

Table 1. Distribution of the Respondents based on Availability of Resources for Online Learning

\begin{tabular}{ccccc}
\hline CLUSTER & $\begin{array}{c}\text { with functional gadgets } \\
\text { for online class }\end{array}$ & $\mathbf{\%}$ & $\begin{array}{c}\text { with gadgets but limited } \\
\text { functionality for online class }\end{array}$ & $\%$ \\
\hline HUMANITIES & 56 & 24.6 & 53 & 32.7 \\
BUSINESS & 42 & 18.4 & 37 & 22.8 \\
TECHNOLOGY & 63 & 27.6 & 32 & 24.7 \\
ALLIED HEALTH & 67 & 29.4 & 162 & 19.8 \\
CAMPUS-WIDE (n) & 228 & 100 & $\mathbf{4 1 . 5 4}$ & \\
\hline Over-all Percent $(\mathbf{N}=\mathbf{3 9 0})$ & $\mathbf{5 8 . 4 6}$ & & & \\
\hline
\end{tabular}

As reflected in table A, most of the students during the current semester have functional computer devices for online classes $(58.46 \%)$. However, many have gadgets but with limited functionality for online classes $(41.54 \%)$.

Table 2. Distribution of the Respondents based on Internet Connectivity for Online Learning

\begin{tabular}{ccccccc} 
CLUSTER & fast & $\mathbf{\%}$ & slow/ poor & $\mathbf{\%}$ & none & $\mathbf{\%}$ \\
\hline HUMANITIES & 29 & 25.4 & 71 & 29.3 & 9 & 26.5 \\
BUSINESS & 21 & 18.4 & 50 & 20.7 & 8 & 23.5 \\
TECHNOLOGY & 32 & 28.1 & 61 & 25.2 & 10 & 29.4 \\
ALLIED HEALTH & 32 & 28.1 & 60 & 24.8 & 7 & 20.6 \\
CAMPUS-WIDE (n) & 114 & 100.0 & 242 & 100.0 & 34 & 100.0 \\
\hline Over-all Percent & \multirow{2}{*}{29.23} & \multicolumn{2}{|c}{62.05} & & \multicolumn{2}{c}{8.72} \\
(N=390) & & &
\end{tabular}

As presented in table $\mathrm{B}$, most students have slow or poor connectivity for the online classes $(62.05 \%)$. The data shows that some do not have the internet connectivity required for online classes $(8.72 \%)$.

\subsection{Sampling and Sample Size}


The 327 online students of the UPHSD-Calamba, selected randomly from the academic clusters, served as the respondents. The study considered only the bonafide students of the campus for the current semester $\left(1^{\text {st }}\right.$ semester, AY 2020-2021) under the flexible learning option (FLO) of online learning, as determined by the faculty through the official class lists were considered as respondents of the study. The sample size yields an achieved statistical power of .999 for correlation analysis and .986 to analyze variance under a medium effect size (.30 and .25 respectively) and .05 alpha error probability.

\subsection{The Instrument of the Study}

The e-questionnaire is composed of 3 parts: Part 1 yields data about their profile; Part 2 comprises nine general statements that reflect the level of quality of education in terms of the services of the institution which are relevant to the new normal; Part 3 is composed of two sub-parts under the SEL Practices of Social and Instructional Interactions comprising of 23 and 26 items, respectively. Part 2 and 3 sets of statements have response options ranging from 1-4. The reliability estimates for the 23 items on Social Interaction SEL Practices is .983, while for the 26 statements on Instructional Competencies is .988 using Cronbach's Alpha. The results of reliability analysis suggest high acceptability of the items for both the sets of questionnaires. The SEL Teaching Practices reflected in the Tool for Teachers in SelfAssessing Social and Emotional Instruction, and Competencies by Yoder (2014) served as the main reference. However, the items were revised to suit the purpose and feasibility of the study.

\subsection{Data Gathering Procedures}

The study utilized an e-survey in the gathering of quantitative data. The e-survey was conducted from November 05 to 11, 2020, through google forms. The forms were distributed to the student-respondents through their official LMS accounts. The data were collected from google form responses and imported as an excel file in preparation for data analysis.

\subsection{Data Analysis}

The research used the IBM-SPSS version 22 software in the statistical analysis of data. The specific statistical tools used were: (1) frequency count and percent in determining the distribution of the respondents according to profile, (2) the weighted mean (with fractional ranking) in determining the levels of quality of education through the delivery of e-services and extent of implementation of SEL Teaching Practices, (3) the ANOVA, One-way in determining the variance in the levels of quality of education through the delivery of eservices and extent of implementation of SEL Teaching Practices when the respondents are classified according to their profile, and (4) the bivariate correlation analysis (Pearson r) in determining the relationship in the levels of quality of education through the delivery of eservices and extent of implementation of SEL Teaching Practices.

\subsection{Ethical Considerations}

The study complied with the ethical standards in the conduct and reporting of results in research. The researcher included the Institutional Data Privacy Act compliance and consent 
to participate in the survey clauses before the data collection. Necessary steps were conducted to ensure the truthfulness of data, and the results were reported in aggregate only.

\section{Findings}

\subsection{Profile of the Online Student-Respondents}

Table 3. Distribution of the Respondents in terms of Cluster Affiliation

\begin{tabular}{ccc}
\hline Cluster Affiliation & Frequency & Percent \\
\hline Allied Health & 136 & 41.6 \\
Business & 31 & 9.5 \\
Humanities and Social Sciences (HUMSS) & 134 & 41.0 \\
Technology & 26 & 8.0 \\
Total & $\mathbf{3 2 7}$ & $\mathbf{1 0 0 . 0}$ \\
\hline
\end{tabular}

As presented in table 3, most of the respondents are from the Allied Health and HUMSS clusters, comprising $41.6 \%$ and $41 \%$, respectively. A few respondents come from the Technology and Business clusters. This turn out in the responses is consistent with the previous survey on internet connectivity and availability of technology for online learning.

Table 4. Distribution of the Respondents in terms of Year-level

\begin{tabular}{ccc}
\hline Year-Level & Frequency & Percent \\
\hline $1^{\text {st }}$ & 145 & 44.3 \\
$2^{\text {nd }}$ & 136 & 41.6 \\
$3^{\text {rd }}$ & 46 & 14.1 \\
Total & $\mathbf{3 2 7}$ & $\mathbf{1 0 0 . 0}$ \\
\hline
\end{tabular}

Table 4 displays that most of the respondents are $1^{\text {st }}$ and $2^{\text {nd }}$-year students, comprising 44.3 and 41.6 of the total, respectively. There are only a few respondents who are in their $3^{\text {rd }}$ year of schooling (14.1\%). The figures shown are consistent with the enrolment statistics of the institution where the bulk of enrollees are from the $1^{\text {st }}$ and $2^{\text {nd }}$ years who are under the new curriculum. The distribution may reflect a younger group of respondents.

\subsection{Quality of Education}

As reflected in table 2, the respondents rated the quality of education of the institution as good through the over-all mean of 3.32. The general result is consistent with all the specific educational e-services, where the rating is also good. This implies that student-respondents have a positive view of the quality of education of the institution in general. It reflects that the institution has adapted to the new normal by shifting to virtual or e-services of its key functions. With excellence as the end in mind, there is still a need to strengthen the quality assurance mechanisms to gain feedback that translates to excellent ratings.

Table 5. Quality of the Education through the Delivery of e-Services

\begin{tabular}{cccc}
\hline \multicolumn{2}{c}{ Item Statements } & & \\
(In general, how do you rate the quality of education of the & Mean & Interpretation & Rank \\
University during this new normal along the area of...) & & & \\
\hline 1. Virtual Faculty & 3.06 & Good & 9 \\
2. Online Instruction & 3.45 & Good & 2 \\
\hline
\end{tabular}




\begin{tabular}{|c|c|c|c|}
\hline $\begin{array}{l}\text { Item Statements } \\
\text { (In general, how do you rate the quality of education of the } \\
\text { University during this new normal along the area of...) }\end{array}$ & Mean & Interpretation & Rank \\
\hline 3. Simulated/Virtual Laboratories & 3.23 & Good & 7 \\
\hline 4. Research & 3.32 & Good & 6 \\
\hline 5. Virtual Library (learning resource center) & 3.19 & Good & 8 \\
\hline 6. Online/ Student e-Services (SPS) & 3.38 & Good & 4 \\
\hline $\begin{array}{l}\text { 7. Virtual Facilities and Learning Management } \\
\text { Systems }\end{array}$ & 3.37 & Good & 5 \\
\hline 8. Philosophy and Objectives & 3.43 & Good & 3 \\
\hline 9. Virtual Administrators & 3.46 & Good & 1 \\
\hline Over-all Mean & 3.32 & Good & \\
\hline
\end{tabular}

Legend: (4) 3.50-4.00 Excellent, (3) 2.50-3.49 Good, (2) 1.50-2.49 Poor, (1) 1.00-1.49 Very Poor

Upon ranking, the respondents provided the highest rating to the virtual administrators (3.46), followed by online instruction (3.45) and Philosophy and Objectives (3.43). These results reflect the strengths of the institution during this new normal. Having virtual administrators being highly ranked is an appreciation of the efforts of the administrators to reach out through different online platforms amid the pandemic. They have strengthened the information dissemination and discussion opportunities through the creation of departmental group chats and Facebook pages; and monitoring of students' progress through the student LMS and administrative management system (School Automate). The delivery instruction through online modalities has also been highly ranked by the students, implying a commendable degree of preparedness for the new normal teaching and learning processes. It can be said that the institution has been successful in its pedagogical shift in instruction. Finally, the Philosophy and Objectives of the institution has also been ranked highly by the respondents. This component-area of the institution has been the source of the quality assurance efforts of the institution. The results, therefore, imply that the Philosophy and Objectives of the institution are highly relevant to the current needs and demands of times where the academic community relies on in times of crisis caused by the pandemic.

On the other hand, the quality of e-services through the virtual faculty (3.06), virtual library (3.19), and virtual laboratories (3.23) have been rated the lowest. The results point out that there is a need to make conscious quality assurance efforts directed towards providing professional development to the faculty and attend to their needs during this new normal teaching environment. There are also acknowledged deficiencies in the services by the library and laboratories.

\subsection{SEL Practices during the New Normal}

As presented in table 3.1, the teachers have implemented the SEL teaching practices under social interaction (over-all mean=3.72). All the specific social interaction SEL teaching practice indicators and its statements have been implemented well during the online classes, as assessed by them. Among the indicators, the students highly rated their teachers' appropriate use of language in teaching has encouraged them to exert more effort to improve in learning (3.80).

On the other hand, the students rated lowly the student-centered discipline among the rest of the indicators under social interaction as SEL teaching practice (3.67). This is reflective of the classroom management that teachers use during the conduct of online classes. Although the students assessed this as implemented well, there is still much room for the teachers to 
improve how they interact with the students during online classes. The improvement may focus on using more developmentally appropriate discipline strategies and the avoidance of over management during classes. Over-all, the results imply that the faculty have adapted well to the shift to online teaching modality given the abruptness of its implementation. However, to fully develop the students with SEL skills and eventually protect them from the adverse effects of the pandemic, the faculty need to enhance how to interact socially with the online learners.

Table 6. Descriptive Statistics on the Implementation of Social Interaction SEL Teaching Practices

\begin{tabular}{|c|c|c|}
\hline $\begin{array}{l}\text { Item Statements } \\
\text { (The teachers...) }\end{array}$ & Mean & Interpretation \\
\hline $\begin{array}{l}\text { 1. have discussions with us about how and why classroom } \\
\text { procedures are implemented. }\end{array}$ & 3.72 & Implemented well \\
\hline $\begin{array}{l}\text { 2. implement consequences that are logical to the rule that is } \\
\text { broken. }\end{array}$ & 3.51 & Implemented well \\
\hline $\begin{array}{l}\text { 3. are consistent in implementing classroom rules and } \\
\text { consequences. }\end{array}$ & 3.58 & Implemented well \\
\hline $\begin{array}{l}\text { 4. respond to misbehavior by considering pupil specific social, } \\
\text { affective, cognitive, and/or environmental factors that are } \\
\text { associated with the occurrence of the behavior }\end{array}$ & 3.60 & Implemented well \\
\hline $\begin{array}{l}\text { 5. allows class discussions so that we can solve class } \\
\text { problems. }\end{array}$ & 3.78 & Implemented well \\
\hline $\begin{array}{l}\text { 6. ask us to reflect and redirect our behavior when we } \\
\text { misbehave }\end{array}$ & 3.67 & Implemented well \\
\hline $\begin{array}{l}\text { 7. teach us strategies to handle the emotions that affect our } \\
\text { learning }\end{array}$ & 3.61 & Implemented well \\
\hline $\begin{array}{l}\text { 8. model strategies that will help us to monitor and regulate } \\
\text { our behavior. }\end{array}$ & 3.58 & Implen \\
\hline Student-Centered Discipline Mean & 3.67 & d well \\
\hline $\begin{array}{l}\text { 1. promote positive behaviors by encouraging us when they } \\
\text { display good social skills }\end{array}$ & 3.76 & Implemented well \\
\hline $\begin{array}{l}\text { 2. promote positive behaviors by encouraging us when they } \\
\text { display good work habits }\end{array}$ & 3.81 & Implemented well \\
\hline $\begin{array}{l}\text { 3. let us know how our effort leads to positive results with } \\
\text { specific affirmation. }\end{array}$ & 3.76 & Implemented well \\
\hline Teacher Language Mean & 3.80 & Implemented well \\
\hline $\begin{array}{l}\text { 1. let us help plan how we are going to learn in } \\
\text { developmentally appropriate ways. }\end{array}$ & 3.68 & Implemented well \\
\hline $\begin{array}{l}\text { 2. for our input when making decisions about how the } \\
\text { classroom will operate in developmentally appropriate } \\
\text { ways. }\end{array}$ & 3.66 & Implemented well \\
\hline 3. give us meaningful choices on what they can work on. & 3.69 & Implemented well \\
\hline $\begin{array}{l}\text { 4. make sure that we make the connection between our } \\
\text { choices and potential consequences. }\end{array}$ & 3.66 & Implemented well \\
\hline $\begin{array}{l}\text { 5. arrange experiences that allow us to become responsible in } \\
\text { developmentally appropriate ways. }\end{array}$ & 3.76 & Implemented well \\
\hline Responsibility and Choice Mean & 3.69 & Implemented well \\
\hline $\begin{array}{l}\text { 1. demonstrate to us that they appreciate us as individuals } \\
\text { (e.g., greeting us by name). }\end{array}$ & 3.78 & Implen \\
\hline 2. use our interests and experiences when teaching. & 3.72 & ted well \\
\hline 3. display to us that they care about how and what we learn. & 3.72 & Implemented well \\
\hline 4. let us know that it is okay to get answers wrong or think & 3.73 & Implemented well \\
\hline
\end{tabular}




\begin{tabular}{|c|c|c|}
\hline $\begin{array}{l}\text { Item Statements } \\
\text { (The teachers...) }\end{array}$ & Mean & Interpretation \\
\hline $\begin{array}{l}\text { outside of the box (e.g., modeling, praising attempts with } \\
\text { "good thinking"). }\end{array}$ & & \\
\hline $\begin{array}{l}\text { 5. check on us about academic and nonacademic concerns we } \\
\text { might have. }\end{array}$ & 3.63 & Implemented well \\
\hline 6. follow up with us when we have a problem or concern. & 3.69 & Implemented well \\
\hline $\begin{array}{l}\text { 7. create structures in the virtual classroom where we feel } \\
\text { included and appreciated (e.g., morning meetings, small } \\
\text { moments) }\end{array}$ & 3.67 & Implemented well \\
\hline $\begin{array}{l}\text { Warmth and Support Mean } \\
\text { Over-all Mean }\end{array}$ & $\begin{array}{l}3.71 \\
3.72\end{array}$ & $\begin{array}{l}\text { Implemented well } \\
\text { Implemented well }\end{array}$ \\
\hline
\end{tabular}

Similarly, as shown in Table 3.2, the teachers have also implemented well the SEL teaching practices in terms of instructional interaction (over-all mean=3.70). The results in the specific indicators and the corresponding statements are also consistent with this general assessment. Specifically, the students viewed as most implemented among the indicators are on both cooperative learning and self-assessment and reflection (3.72). This implies that the teachers have done well in making students work together to achieve a collective goal during online classes. Along with this, the teachers have allowed the students to reflect on their own work towards self-improvement.

On the other hand, the students rated least the implementation of SEL teaching practice in balanced instruction (3.67) among the instructional interaction indicators. This implies that based on the students' assessment, the faculty have yet to fully find the appropriate combination of direct and active instruction during online classes. The students further pointed out the need to have them work on products that are meant to be shared with multiple audiences (3.64). The faculty may need to carefully plan the required activities and outputs during the teaching and learning process in the new normal.

Table 7. Descriptive Statistics on the Implementation of Instructional Interaction SEL Teaching Practices

\begin{tabular}{lcc}
\hline \multicolumn{1}{c}{$\begin{array}{c}\text { Item Statements } \\
\text { (The teachers...) }\end{array}$} & Mean & Interpretation \\
\hline $\begin{array}{l}\text { 1. encourage us to work with other students when we have } \\
\text { trouble with an assignment. }\end{array}$ & 3.69 & Implemented well \\
$\begin{array}{l}\text { 2. create learning experiences in which classmates depend on } \\
\text { each other. }\end{array}$ & 3.67 & Implemented well \\
$\begin{array}{l}\text { 3. create learning experiences in which we must apply positive } \\
\text { social skills to be successful. }\end{array}$ & 3.74 & Implemented well \\
$\begin{array}{l}\text { 4. hold individuals and the group accountable for learning } \\
\text { during small-group work }\end{array}$ & 3.72 & Implemented well \\
$\begin{array}{l}\text { 5. provide opportunities for us to share our work and receive } \\
\text { feedback from each other. }\end{array}$ & 3.68 & Implemented well \\
$\begin{array}{l}\text { 6. provide space to collaboratively process how we work } \\
\text { together and monitor our progress toward our goal. }\end{array}$ & 3.73 & Implemented well \\
$\begin{array}{l}\text { 7. give us feedback on how we interact with and learn from } \\
\text { others during cooperative learning experiences. }\end{array}$ & 3.66 & Implemented well \\
$\quad$ Cooperative Learning Mean & $\mathbf{3 . 7 2}$ & Implemented well \\
$\begin{array}{l}\text { 1. help us identify how to listen } \\
\text { holm }\end{array}$ & 3.70 & Implemented well
\end{tabular}




\begin{tabular}{|c|c|c|}
\hline $\begin{array}{l}\text { Item Statements } \\
\text { (The teachers...) }\end{array}$ & Mean & Interpretation \\
\hline $\begin{array}{l}\text { 2. help us learn how to respond to and learn from peers' } \\
\text { contributions during a discussion. }\end{array}$ & 3.71 & Implemented well \\
\hline $\begin{array}{l}\text { 3. help us learn how to effectively communicate our points of } \\
\text { view }\end{array}$ & 3.73 & Implemented well \\
\hline 4. hold in-depth discussions about content with us & 3.69 & Implemen \\
\hline $\begin{array}{l}\text { 5. ask us to listen to and think about our peers' opinions and } \\
\text { whether we agree with them }\end{array}$ & 3.66 & Implemented well \\
\hline Classroom Discussions Mean & 3.71 & Implemented well \\
\hline 1. inform us of the learning goals for each lesson. & 3.75 & Implemented well \\
\hline 2. have us reflect on our personal academic goals & 3.71 & Implemented well \\
\hline 3. provide us strategies to analyze our work & 3.71 & Implemented well \\
\hline $\begin{array}{l}\text { 4. create opportunities for us to monitor and reflect on our } \\
\text { progress toward our learning goals. }\end{array}$ & 3.70 & Implemented well \\
\hline $\begin{array}{l}\text { 5. create opportunities for us to monitor and reflect on our } \\
\text { social learning. }\end{array}$ & 3.71 & Implemented well \\
\hline $\begin{array}{l}\text { 6. help us develop strategies to make sure we meet their } \\
\text { learning goals. }\end{array}$ & 3.67 & Implemented well \\
\hline $\begin{array}{l}\text { 7. provide us opportunities to reflect on our thinking and } \\
\text { learning processes }\end{array}$ & 3.72 & Implemented well \\
\hline $\begin{array}{l}\text { 8. ask us to think together to provide feedback on the } \\
\text { effectiveness of learning activities }\end{array}$ & 3.70 & Implemented well \\
\hline Self-Assessment and Self-Reflection Mean & 3.72 & Implemented well \\
\hline $\begin{array}{l}\text { 1. use an appropriate balance between providing us } \\
\text { opportunities to directly learn new information and actively } \\
\text { engage in the material. }\end{array}$ & 3.65 & Implemented well \\
\hline $\begin{array}{l}\text { 2. have our work on some extended projects that require at least } \\
\text { one week to complete. }\end{array}$ & 3.66 & Implemented well \\
\hline $\begin{array}{l}\text { 3. require us to extend our thinking when we provide basic } \\
\text { answers }\end{array}$ & 3.71 & Implemented well \\
\hline $\begin{array}{l}\text { 4. use multiple instructional strategies to keep us engaged in } \\
\text { learning }\end{array}$ & 3.67 & Implemented well \\
\hline $\begin{array}{l}\text { 5. make sure that our activities are not just fun but represent } \\
\text { one of the best ways for us to learn the content. }\end{array}$ & 3.70 & Implemented well \\
\hline $\begin{array}{l}\text { 6. ask us to work on products that are meant to be shared with } \\
\text { multiple audiences }\end{array}$ & 3.64 & $\operatorname{Im}$ \\
\hline $\begin{array}{l}\text { Balanced Instruction Mean } \\
\text { Over-all Mean }\end{array}$ & $\begin{array}{l}3.67 \\
3.70\end{array}$ & $\begin{array}{l}\text { Implemented well } \\
\text { Implemented Well }\end{array}$ \\
\hline
\end{tabular}

Legend: 1.00-1.49 (1)—not implemented; 1.50-2.49 (2)—struggled to implement; 2.50-3.49 (3) Implemented reasonably well; 4-Implemented well; 5-implemented extremely well.

\subsection{Differences in the Assessment on Quality of Education}

As displayed in table 4.1, there exists no significant difference in the assessments of the respondents who are affiliated to different clusters on the level of quality of education through the delivery of e-services during the new normal since all the computed p-values are greater than the .05 level of significance. It can be said that regardless of the students' courses, they have similar ratings on the level of quality of education during the new normal. This reflects that there is consensus among the students belonging to the different academic clusters on the delivery of quality education of the institution. 
Table 8. Analysis of Variance in the Quality of Education by Cluster Affiliation

\begin{tabular}{|c|c|c|c|c|c|c|}
\hline \multicolumn{2}{|l|}{ VARIABLES } & Sum of Squares & df & Mean Square & $\mathbf{F}$ & Sig. \\
\hline \multirow{3}{*}{ Virtual Faculty } & Between Groups & 2.003 & 3 & .668 & 1.741 & .158 \\
\hline & Within Groups & 123.893 & 323 & .384 & & \\
\hline & Total & 125.896 & 326 & & & \\
\hline \multirow{3}{*}{ Online instruction } & Between Groups & 2.513 & 3 & .838 & 1.116 & .343 \\
\hline & Within Groups & 242.404 & 323 & .750 & & \\
\hline & Total & 244.917 & 326 & & & \\
\hline \multirow{3}{*}{ Simulated/virtual laboratories } & Between Groups & 2.695 & 3 & .898 & 1.025 & .382 \\
\hline & Within Groups & 283.103 & 323 & .876 & & \\
\hline & Total & 285.798 & 326 & & & \\
\hline \multirow{3}{*}{ Research } & Between Groups & .790 & 3 & .263 & .337 & .799 \\
\hline & Within Groups & 252.494 & 323 & .782 & & \\
\hline & Total & 253.284 & 326 & & & \\
\hline \multirow{3}{*}{ virtual library (learning resource center) } & Between Groups & 2.694 & 3 & .898 & .983 & .401 \\
\hline & Within Groups & 294.927 & 323 & .913 & & \\
\hline & Total & 297.621 & 326 & & & \\
\hline \multirow{3}{*}{ Online Student Services } & Between Groups & 2.705 & 3 & .902 & 1.048 & .372 \\
\hline & Within Groups & 278.029 & 323 & .861 & & \\
\hline & Total & 280.734 & 326 & & & \\
\hline \multirow{3}{*}{ Virtual Facilities and Learning Systems } & Between Groups & 3.261 & 3 & 1.087 & 1.287 & .279 \\
\hline & Within Groups & 272.702 & 323 & .844 & & \\
\hline & Total & 275.963 & 326 & & & \\
\hline \multirow{3}{*}{ Philosophy and Objectives } & Between Groups & 1.378 & 3 & .459 & .573 & .633 \\
\hline & Within Groups & 258.824 & 323 & .801 & & \\
\hline & Total & 260.202 & 326 & & & \\
\hline \multirow{3}{*}{ Virtual Administrators } & Between Groups & 3.629 & 3 & 1.210 & 1.591 & .191 \\
\hline & Within Groups & 245.643 & 323 & .761 & & \\
\hline & Total & 249.272 & 326 & & & \\
\hline \multirow{3}{*}{ Quality of Education E-Services } & Between Groups & 2.504 & 3 & .835 & 1.230 & .299 \\
\hline & Within Groups & 219.135 & 323 & .678 & & \\
\hline & Total & 221.639 & 326 & & & \\
\hline
\end{tabular}

The test used: ANOVA, One-Way; .05 level of significance

However, when the respondents are grouped according to the year-level, a different result is shown. As displayed in table 4.2, there are significant differences in the assessments in the level of quality of education through the delivery of e-services when the respondents are grouped according to their year-level since the computed p-values are lesser than the .05 level of significance. The result is consistent with the e-services in general and on all the specific eservices. This implies that unlike in the academic cluster affiliation, year-level is a factor in assessing the quality of education of the institution during the new normal.

Table 9. Analysis of Variance in the Quality of Education by Year-level

\begin{tabular}{llccccc}
\multicolumn{6}{c}{ Table 9. Analysis of Variance in the Quality of Education by Year-level } \\
\hline \multicolumn{2}{c}{ VARIABLES } & Sum of Squares & df & Mean Square & F & Sig. \\
\hline \multirow{3}{*}{ Virtual Faculty } & Between Groups & 13.471 & 2 & 6.736 & 19.411 & .000 \\
& Within Groups & 112.425 & 324 & .347 & & \\
& Total & 125.896 & 326 & & & \\
Online instruction & Between Groups & 30.905 & 2 & 15.453 & 23.394 & .000 \\
& Within Groups & 214.012 & 324 & .661 & & \\
\multirow{5}{*}{ Simulated/virtual laboratories } & Total & 244.917 & 326 & & & \\
& Between Groups & 25.349 & 2 & 12.674 & 15.767 & .000 \\
& Within Groups & 260.450 & 324 & .804 & & \\
Research & Total & 285.798 & 326 & & & \\
& Between Groups & 29.657 & 2 & 14.829 & 21.484 & .000 \\
virtual library (learning & Within Groups & 223.627 & 324 & .690 & & \\
\hline
\end{tabular}




\begin{tabular}{|c|c|c|c|c|c|c|}
\hline \multicolumn{2}{|c|}{ VARIABLES } & \multirow{2}{*}{$\begin{array}{c}\text { Sum of Squares } \\
269.061\end{array}$} & \multirow{2}{*}{$\begin{array}{c}\text { df } \\
324\end{array}$} & \multirow{2}{*}{$\begin{array}{c}\text { Mean Square } \\
.830\end{array}$} & \multirow[t]{2}{*}{$\mathbf{F}$} & \multirow[t]{2}{*}{ Sig. } \\
\hline resource center) & Within Groups & & & & & \\
\hline & Total & 297.621 & 326 & & & \\
\hline \multirow{3}{*}{ Online Student Services } & Between Groups & 30.823 & 2 & 15.412 & 19.981 & .000 \\
\hline & Within Groups & 249.911 & 324 & .771 & & \\
\hline & Total & 280.734 & 326 & & & \\
\hline \multirow{3}{*}{$\begin{array}{l}\text { Virtual Facilities and } \\
\text { Learning Systems }\end{array}$} & Between Groups & 22.578 & 2 & 11.289 & 14.435 & .000 \\
\hline & Within Groups & 253.386 & 324 & .782 & & \\
\hline & Total & 275.963 & 326 & & & \\
\hline \multirow{3}{*}{ Philosophy and Objectives } & Between Groups & 23.056 & 2 & 11.528 & 15.750 & .000 \\
\hline & Within Groups & 237.146 & 324 & .732 & & \\
\hline & Total & 260.202 & 326 & & & \\
\hline \multirow{3}{*}{ Virtual Administrators } & Between Groups & 30.905 & 2 & 15.452 & 22.927 & .000 \\
\hline & Within Groups & 218.368 & 324 & .674 & & \\
\hline & Total & 249.272 & 326 & & & \\
\hline \multirow{4}{*}{$\begin{array}{l}\text { Quality of Education E- } \\
\text { Services }\end{array}$} & Between Groups & 23.162 & 2 & 11.581 & 18.905 & .000 \\
\hline & Within Groups & 198.477 & 324 & .613 & & \\
\hline & Total & 221.639 & 326 & & & \\
\hline & Total & 218.550 & 326 & & & \\
\hline
\end{tabular}

Test used: ANOVA, One-Way; .05 level of significance

Note: In all indicators: $1^{\text {st }}$ Year $>2^{\text {nd }}$ and $3^{\text {rd }}$ Year, using Scheffe Post-Hoc Analysis; subset for alpha $=.05$

Upon further analysis, the $1^{\text {st }}$ year students have significantly higher assessments in the level of quality of education compared to both the $2^{\text {nd }}$ and $3^{\text {rd }}$ year students. A possible consideration that explains this phenomenon is the external comparison of the $1^{\text {st }}$ years in delivering services between their previous institutions (SHS) and the current institution. It may imply that they highly rated the quality of education of the university during the new normal based on their previously set expectations. While in the case of the $2^{\text {nd }}$ year and $3^{\text {rd }}$ year students, they have already experienced how the delivery of services during the old normal. The varying groups have contextual differences in so far as the setting of standards is concerned.

\subsection{Differences in the Assessment on SEL Teaching Practices}

Table 10. Analysis of Variance in the SEL Teaching Practices by Cluster Affiliation

\begin{tabular}{llccccc}
\hline \multicolumn{2}{c}{ VARIABLES } & Sum of Squares & df & Mean Square & F & Sig. \\
\hline \multirow{2}{*}{ Student-Centered Discipline } & Between Groups & 2.822 & 3 & .941 & 1.359 & .255 \\
Mean & Within Groups & 223.509 & 323 & .692 & & \\
& Total & 226.330 & 326 & & & \\
& Between Groups & 4.800 & 3 & 1.600 & 2.013 & .112 \\
Teacher Language Mean & Within Groups & 256.674 & 323 & .795 & & \\
& Total & 261.474 & 326 & & & \\
Responsibility and Choice & Between Groups & 1.979 & 3 & .660 & .846 & .469 \\
Mean & Within Groups & 251.825 & 323 & .780 & & \\
& Total & 253.804 & 326 & & & \\
Warmth and Support & Between Groups & 4.180 & 3 & 1.393 & 2.031 & .109 \\
& Within Groups & 221.637 & 323 & .686 & & \\
Overall Social Interactions & Total & 225.817 & 326 & & & \\
& Between Groups & 3.519 & 3 & 1.173 & 1.717 & .163 \\
& Within Groups & 220.597 & 323 & .683 & & \\
& Total & 224.116 & 326 & & & \\
Cooperative Learning Mean & Between Groups & 2.660 & 3 & .887 & 1.326 & .266 \\
& Within Groups & 215.891 & 323 & .668 & & \\
Classroom Discussions & Total & 218.550 & 326 & & & \\
& Between Groups & 3.885 & 3 & 1.295 & 1.937 & .123 \\
\hline
\end{tabular}




\begin{tabular}{llccccc}
\hline \multicolumn{1}{c}{ VARIABLES } & Sum of Squares & df & Mean Square & F & Sig. \\
\hline & Total & 219.817 & 326 & & & \\
Self-Assessment and Self- & Between Groups & 3.049 & 3 & 1.016 & 1.629 & .182 \\
Reflection & Within Groups & 201.502 & 323 & .624 & & \\
& Total & 204.550 & 326 & & & \\
Balanced Instruction & Between Groups & 3.367 & 3 & 1.122 & 1.761 & .154 \\
& Within Groups & 205.825 & 323 & .637 & & \\
Over-all Instructional & Total & 209.192 & 326 & & & \\
Interactions & Between Groups & 2.282 & 3 & .761 & 1.304 & .273 \\
& Within Groups & 188.472 & 323 & .584 & & \\
Over-all SEL Teaching & Total & 190.754 & 326 & & & \\
Practices & Between Groups & 2.503 & 3 & .834 & 1.429 & .234 \\
& Within Groups & 188.539 & 323 & .584 & & \\
\hline
\end{tabular}

The test used: ANOVA, One-Way; .05 level of significance

As displayed in table 5.1, there exists no significant difference in the assessments of the respondents who are affiliated to different clusters on the level of implementation of SEL teaching practices during the new normal since all the computed p-values are greater than the .05 level of significance. It can be said that regardless of the students' courses, there is consensus among the students belonging to the different academic clusters on the level of implementation of SEL teaching practices. On the other hand, as shown in Table 5.2, there exist significant differences in the assessment on the level of implementation of all SEL teaching practices since the computed p-values are lesser than the .05 level of significance. Furthermore, the freshmen students are those who have significantly higher assessments in this aspect compared to the old students ( $2^{\text {nd }}$ and $3^{\text {rd }}$ years).

Table 11. Analysis of Variance in the SEL Teaching Practices by Year-level

\begin{tabular}{|c|c|c|c|c|c|c|}
\hline VARIABLES & & Sum of Squares & df & Mean Square & $\mathbf{F}$ & Sig. \\
\hline \multirow{3}{*}{ Student-Centered Discipline Mean } & Between Groups & 16.918 & 2 & 8.459 & 13.088 & .000 \\
\hline & Within Groups & 209.412 & 324 & .646 & & \\
\hline & Total & 226.330 & 326 & & & \\
\hline \multirow{3}{*}{ Teacher Language Mean } & Between Groups & 20.659 & 2 & 10.329 & 13.897 & .000 \\
\hline & Within Groups & 240.815 & 324 & .743 & & \\
\hline & Total & 261.474 & 326 & & & \\
\hline \multirow{3}{*}{ Responsibility and Choice Mean } & Between Groups & 11.862 & 2 & 5.931 & 7.942 & .000 \\
\hline & Within Groups & 241.943 & 324 & .747 & & \\
\hline & Total & 253.804 & 326 & & & \\
\hline \multirow{3}{*}{ Warmth and Support } & Between Groups & 19.988 & 2 & 9.994 & 15.732 & .000 \\
\hline & Within Groups & 205.828 & 324 & .635 & & \\
\hline & Total & 225.817 & 326 & & & \\
\hline \multirow{3}{*}{ Overall Social Interactions } & Between Groups & 13.989 & 2 & 6.994 & 10.785 & .000 \\
\hline & Within Groups & 210.128 & 324 & .649 & & \\
\hline & Total & 224.116 & 326 & & & \\
\hline \multirow{3}{*}{ Cooperative Learning Mean } & Between Groups & 16.494 & 2 & 8.247 & 13.224 & .000 \\
\hline & Within Groups & 202.057 & 324 & .624 & & \\
\hline & Total & 218.550 & 326 & & & \\
\hline \multirow{3}{*}{ Classroom Discussions } & Between Groups & 19.758 & 2 & 9.879 & 15.999 & .000 \\
\hline & Within Groups & 200.058 & 324 & .617 & & \\
\hline & Total & 219.817 & 326 & & & \\
\hline \multirow{3}{*}{ Self-Assessment and Self-Reflection } & Between Groups & 18.134 & 2 & 9.067 & 15.759 & .000 \\
\hline & Within Groups & 186.416 & 324 & .575 & & \\
\hline & Total & 204.550 & 326 & & & \\
\hline \multirow{3}{*}{ Balanced Instruction } & Between Groups & 21.122 & 2 & 10.561 & 18.194 & .000 \\
\hline & Within Groups & 188.070 & 324 & .580 & & \\
\hline & Total & 209.192 & 326 & & & \\
\hline Over-all Instructional Interactions & Between Groups & 17.738 & 2 & 8.869 & 16.608 & .000 \\
\hline
\end{tabular}




\begin{tabular}{clccccc}
\hline VARIABLES & & Sum of Squares & df & Mean Square & F & Sig. \\
\hline & Within Groups & 173.016 & 324 & .534 & & \\
& Total & 190.754 & 326 & & & \\
& Between Groups & 17.155 & 2 & 8.578 & 15.982 & .000 \\
Over-all SEL Teaching Practices & Within Groups & 173.886 & 324 & .537 & & \\
& Total & 191.042 & 326 & & & \\
\hline
\end{tabular}

Note: In all indicators, the $1^{\text {st }}$ Year Group have significantly higher assessments compared to the $2^{\text {nd }}$ and $3^{\text {rd }}$ Year Groups, using Scheffe Post-Hoc Analysis; subset for alpha $=.05$

As previously explained, the points of reference and expectations regarding online instruction may contribute to the differences in the assessments. It must be noted, though, that although there is a significant difference in the assessment in the level of implementation, the fact remains that there is a need to improve to extremely well implementation. This is stressed in recognition of the crucial role of integrating SEL into instruction to develop highly resilient students, in the light of the pandemic.

\subsection{Quality of Education and SEL Teaching Practices}

Table 6. Correlation Analysis on Implementation of SEL Practices and Quality of the Education

\begin{tabular}{|c|c|c|c|c|c|c|c|c|c|c|}
\hline VARIABLES & Virtual Faculty & $\begin{array}{l}\text { On-line } \\
\text { instruction }\end{array}$ & $\begin{array}{c}\text { simulated/ } \\
\text { virtual } \\
\text { laboratories }\end{array}$ & research & virtual library & $\begin{array}{l}\text { e-Student } \\
\text { Services }\end{array}$ & $\begin{array}{c}\text { Online } \\
\text { Facilities and } \\
\text { LMS? }\end{array}$ & $\begin{array}{c}\text { Philosophy } \\
\text { and } \\
\text { Objectives }\end{array}$ & $\begin{array}{c}\text { Virtual } \\
\text { Administrators }\end{array}$ & $\begin{array}{c}\text { Over-all } \\
\text { Education E- } \\
\text { Services }\end{array}$ \\
\hline $\begin{array}{l}\text { Student-Centered } \\
\text { Discipline Mean }\end{array}$ & $.511^{*}$ & $.588^{* \prime}$ & $.510^{*}$ & $.571^{*}$ & $.582^{*}$ & $.582^{*}$ & $.635^{\circ}$ & $612^{\prime \prime}$ & $.631^{*}$ & $.674^{\prime \prime}$ \\
\hline Teacher Language Mean & $.467^{*}$ & $.564^{\prime \prime}$ & $.438^{* *}$ & $.500^{\circ}$ & $.520^{*}$ & $.547^{*}$ & $.594^{\prime \prime}$ & $.566^{\prime \prime}$ & $.609^{* *}$ & $.597^{* *}$ \\
\hline $\begin{array}{l}\text { Responsibility and Choice } \\
\text { Mean }\end{array}$ & $.542^{* *}$ & $.579^{*}$ & $.517^{*}$ & $.581^{* *}$ & $.563^{* *}$ & $.573^{*+}$ & $.616^{\circ}$ & $.609^{*}$ & $.619^{* *}$ & $.661^{* \prime}$ \\
\hline Warmth and Support & $.513^{*}$ & $.600^{\circ}$ & $.500^{*}$ & $.576^{*}$ & $.551^{*}$ & $.584^{\prime \prime}$ & $614^{\prime \prime}$ & $.625^{\circ}$ & $.659^{*}$ & $.644^{\prime \prime}$ \\
\hline $\begin{array}{l}\text { Overall Social } \\
\text { Interactions }\end{array}$ & $.526^{* t}$ & $.582^{* t}$ & $.506^{* t}$ & $.577^{*}$ & $.558^{\prime \prime}$ & $.580^{* *}$ & $.634^{* \prime}$ & $.607^{\prime \prime}$ & $.641^{* t}$ & $.663^{* t}$ \\
\hline $\begin{array}{c}\text { Cooperative Learning } \\
\text { Mean }\end{array}$ & $.533^{* *}$ & $.613^{\prime \prime}$ & $.541^{*}$ & $.607^{*}$ & $.574^{* *}$ & $.573^{*}$ & $.636^{\prime \prime}$ & $.608^{\circ \prime}$ & $.660^{*}$ & $.664^{\prime \prime}$ \\
\hline Classroom Discussions & $.508^{* *}$ & $.608^{\prime \prime}$ & $.543^{*}$ & $.580^{* *}$ & $.551^{* *}$ & $.556^{\circ}$ & $.610^{\circ}$ & $600^{\circ}$ & $.676^{*}$ & $.639^{* *}$ \\
\hline $\begin{array}{l}\text { Self-Assessment and Self- } \\
\text { Reflection }\end{array}$ & $.495^{*}$ & $.571^{\prime \prime}$ & $.514^{*}$ & $.562^{* *}$ & $.557^{*}$ & $.597^{\circ}$ & $.598^{*}$ & $.625^{\prime \prime}$ & $.611^{* *}$ & $.635^{* *}$ \\
\hline Balanced Instruction & $.521^{* *}$ & $.640^{\circ}$ & $.557^{*}$ & $.600^{\circ}$ & $.584^{*}$ & $.622^{*+}$ & $.656^{\prime \prime}$ & $.629^{\prime \prime}$ & $.665^{*}$ & $.685^{\prime \prime}$ \\
\hline $\begin{array}{l}\text { Over-all Instructional } \\
\text { Interactions }\end{array}$ & $.550^{* t}$ & $.646^{* t}$ & $.569^{* \prime}$ & $.621^{* t}$ & $.590^{* \prime}$ & $.618^{\prime \prime}$ & $.659^{\prime \prime}$ & $.648^{\prime \prime}$ & $.692^{* *}$ & $.692^{* 3}$ \\
\hline $\begin{array}{c}\text { Over-all SEL Teaching } \\
\text { Practices }\end{array}$ & $.563^{* t+}$ & $.646^{* t}$ & $.562^{2 *}$ & $.621^{* t}$ & $.605^{* \prime \prime}$ & $.625^{*}$ & $.673^{* *}$ & $.661^{\prime \prime}$ & $.700^{* *}$ & $.705^{1 *}$ \\
\hline
\end{tabular}

Note: *Correlation is significant at .01 level of significance.

As shown in table 6, there is a significant relationship between the quality of education of the institution and its level of implementation of SEL teaching practices based even on a .01 level of significance. This relationship is sweeping to all the delivery of e-services, reflecting the quality of education of the institution and the specific SEL teaching practices. Furthermore, all the relationships are described as strong-positive since the correlation coefficients fall within the range of .40-.60. This implies a strong tendency that when the quality of education of the institution improves, the implementation of SEL teaching practices also improves. However, the same direction may also occur if the other variable declines. The results highlight the need to strengthen QA mechanisms, which translates to improved quality of educational services of the university. Consequently, this may lead to more pandemicresponsive teaching by the faculty, where the aim is to have more resilient learners. 


\section{Conclusions and Directions for Future Use}

a. The online students of the UPHSD are young learners who are vulnerable to the illeffects of the pandemic.

b. The UPHSD has adapted well to delivering educational services, most notably through its online instruction, virtual administrators, and Philosophy and Objectives.

c. The UPSD teachers have implemented well the SEL teaching practices through social and instructional interaction during the pandemic.

d. There is still room for improvement in the delivery of educational services of UPHSD, particularly to loyal clients.

e. The teachers of UPHSD may still enhance the development of SEL, most particularly on the learners who were used to the old normal, through enhancement of online SEL instructional practices.

f. Resilient learners may be developed through continuous improvement in delivering appropriate educational services of UPSHD towards excellence.

g. Concrete SEL integration programs may be infused into the e-services to fully develop resilient members of the academic and the larger community as part of the QA strategies.

\section{References}

[1] A Critical Time For Well-Being. (, 2020). Education Week, 39(29), 4.

[2] American Institutes for Research (AIR). (, 2015). Are You Ready to Assess Social and Emotional Development? SEL Solutions Brief. In American Institutes for Research. American Institutes for Research.

[3] Barnes, T. N., \& McCallops, K. (2019). Perceptions of Culturally Responsive Pedagogy in Teaching SEL. Journal for Multicultural Education, 13(1), 70-81.

[4] Duncan, Robert; Washburn, Isaac J.; Lewis, Kendra M.; Bavarian, Niloofar; DuBois, David L.; Acock, Alan C.; Vuchinich, Samuel; Flay, Brian R., 2020

[5] Eaton, J.S., (2011). U.S. accreditation: Meeting the challenges of accountability and student achievement. Education in Higher Education, 5(1)

[6] Goh, T. L., \& Connolly, M. (2020). Efficacy of School-Based SEL Programs: Aligning with Health and Physical Education Standards. Journal of Physical Education, Recreation \& Dance, 91(5), 16-19.

[7] Herman, Beth \& Collins, Rebecca (2018). Social and Emotional Learning Competencies. Wisconsin Department of Public Instruction. Wisconsin, USA.

[8] Long, D., \& National Association of State Boards of Education (NASBE). (, 2019). School Leaders' Role in Empowering Teachers through SEL. State Innovations. Vol. 24, No. 1. In the National Association of State Boards of Education. National Association of State Boards of Education.

[9] Lundberg, C. A. \& Schreiner, L. A. (2004) Quality and frequency of faculty-student interaction as predictors of learning: An analysis by student race/ethnicity. Journal of College Student Development, 45 (5).

[10] Mehta, J., \& American Enterprise Institute (AEI). (, 2020). How Social and Emotional Learning Can Succeed. In American Enterprise Institute. American Enterprise Institute.

[11] Melnick, H., Cook-Harvey, C. M., Darling-Hammond, L., \& Learning Policy Institute. (, 2017). Encouraging Social and Emotional Learning in the Context of New Accountability. In Learning Policy Institute. Learning Policy Institute. 
[12] Oberle, E., Domitrovich, C. E., Meyers, D. C., \& Weissberg, R. P. (2016). Establishing systemic social and emotional learning approaches in schools: a framework for schoolwide implementation. Cambridge Journal of Education, 46(3), 277-297. https://doi.org/10.1080/0305764X.2015.1125450

[13] Pawlo, E., Lorenzo, A., Eichert, B., \& Elias, M. J. (2019). All SEL Should Be TraumaInformed. Phi Delta Kappan, 101(3), 37-41.

[14] Porche, Michelle; Grossman, Jenny; Biro, Nova; MacKay, Nancy; Rivers, Sojourner; Society for Research on Educational Effectiveness (SREE) 2014

[15] Puzziferro, M. \& Shelton, K. (2008). A model for developing high-quality online courses: Integrating a systems approach with learning theory. Journal of Asynchronous Learning Networks. Newbury, MA. Online Learning Consortium.

[16] Ryan, T. (2015). Quality Assurance in Higher Education: A Review of Literature. Higher Learning Research Communications, 5(4).

[17] Yoder, Nicholas. (, 2014). Self-Assessing Social and Emotional Instruction and Competencies: A Tool for Teachers. Center on Great Teachers and Leaders. American Institutes for Research (AIR) 